\title{
The Effects of Infrastructure Service Disruptions and Socio-Economic Vulnerability on Hurricane Recovery
}

\author{
Diana Mitsova ${ }^{1}$, Monica Escaleras ${ }^{2, *}$, Alka Sapat ${ }^{3}$, Ann-Margaret Esnard ${ }^{4}$ and \\ Alberto J. Lamadrid ${ }^{5}$ \\ 1 School of Urban \& Regional Planning, Florida Atlantic University, Boca Raton, FL 33431, USA; \\ dmitsova@fau.edu \\ 2 Department of Economics, Florida Atlantic University, Boca Raton, FL 33431, USA \\ 3 School of Public Administration, Florida Atlantic University, Boca Raton, FL 33431, USA; asapat@fau.edu \\ 4 Department of Public Management and Policy, Georgia State University, Atlanta, GA 30303, USA; \\ aesnard@gsu.edu \\ 5 Department of Economics, Lehigh University, 621 Taylor Street, Bethlehem, PA 18015, USA; \\ ajlamadrid@lehigh.edu \\ * Correspondence: mescaler@fau.edu
}

Received: 26 November 2018; Accepted: 11 January 2019; Published: 19 January 2019

check for updates

\begin{abstract}
Hurricanes and extreme weather events can cause widespread damage and disruption to infrastructure services and consequently delay household and community recovery. A subset of data from a cross-sectional survey of 989 households in central and south Florida is used to examine the effects of Hurricane Irma on post-disaster recovery eight months after the landfall. Using logistic regression modeling, we find that physical damage to property, disruption of infrastructure services such as loss of electric power and cell phone/internet services and other factors (i.e., homeowner's or renter's insurance coverage, receiving disaster assistance and loss of income) are significant predictors of post-disaster recovery when controlling for age and race/ethnicity.
\end{abstract}

Keywords: hurricane recovery; infrastructure service disruptions; socio-economic vulnerability

\section{Introduction}

Physical damage to structures can cause disruption of infrastructure services, often with cascading impacts on other interdependent infrastructures such as those that exist between electric power, water, transportation, communications and so forth. Impact and damage assessments of hurricanes on housing, businesses, institutional facilities, infrastructure and other physical assets are typical activities performed during post-disaster response to improve recovery timelines. In addition to physical disruptions, socio-economic vulnerabilities may affect the ability of households to recover. Social and economic impacts often linger for subsets of communities and households without access to adequate resources to recover. Socio-economic vulnerability assessments have thus become the norm, with an expanding list of indicators and methods used to inform decision-making about evacuation, shelter and provision of services [1,2]. As noted by Lindell ([3], p. 812), "it is important to anticipate which population segments and economic sectors will have the most difficulty in recovering. This will enable community authorities to intervene with technical and financial assistance when it is needed, monitor their recovery and encourage them to adopt hazard mitigation measures to reduce their hazard vulnerability." The availability of hazard insurance and disaster assistance to aid individuals and families are important factors in this regard. Such financial resources are critical to improving disaster recovery timelines and households' recovery perceptions. Insurance is an important strategy for pre-disaster mitigation and risk management as well, although widespread 
adoption and availability of feasible incentive structures and systems for both homeowners and renters require further investigation [4-6]. Since disaster recovery can vary over time and often overlaps with other phases of the emergency management cycle such as response and mitigation, our focus in this paper is on households' recovery perceptions.

To understand the factors that impact perceptions of household recovery, this paper examines the effects of Hurricane Irma on post-disaster recovery eight months after the landfall in counties across central and south Florida. In Section 2, we begin by providing a brief review of key findings in extant research with respect to the impacts of electric power outages, infrastructure disruptions, socio-economic vulnerabilities, insurance and disaster assistance on household recovery. In Section 3, we discuss our research design and methods that include data collected from a cross-sectional survey of 989 households, which we analyze using logistic regression modeling. We find that physical damage to property, disruptions of infrastructure services such as loss of electric power and cell phone or internet services and resources such as homeowner's or renter's insurance coverage and receiving assistance from FEMA, along with loss of income are significant predictors of households' recovery when controlling for age and race/ethnicity. We conclude the paper with a discussion of the broader implications of the findings, suggesting additional research and policy recommendations to ultimately improve households' recovery processes.

\section{Literature Review}

Hurricanes can cause significant flood and wind damage to housing and infrastructure systems. Electric power outages, in particular, can be very disruptive and have cascading effects on other critical infrastructures [7,8]. However, other factors such as socio-economic vulnerability, insurance and disaster aid in hurricane-prone areas such as Florida are important considerations given the implications for recovery timelines. This literature review is organized into four parts: an overview of the impact of hurricane disasters on critical infrastructure with a focus on power outages; the impacts of social vulnerability on households and the role of resources such as insurance and disaster aid in improving recovery.

\subsection{Infrastructure Disruptions from Hurricanes: A Focus on Electric Power Outages}

The electric power system is critical to the well-functioning performance of a developed economy and is characterized by its capacity to withstand low impact events and continue operating reliably [9]. However, damage to the system by high-impact, low-probability events and resultant electric power outages can lead to significant infrastructure disruptions. Both preventive and corrective approaches have been the subject of active study. For example, after the 2003 blackout in the northeastern portion of North America, systematic inspection and vegetation management have become standard in most systems [10,11]. O'Rourke [7] provides an overview of the evolving concept of resilience, including the general concept of lifeline systems in infrastructure, the interdependencies that arise in critical infrastructure systems and the use of resilience qualities along technical, social and economic dimensions [7].

For preventive management, Wang [8] introduced a statistical tool to forecast what elements of the electric power infrastructure might suffer interruptions and disturbances from hurricanes. The model can be used for forecasting overall system conditions after a hurricane, as well as to provide recommendations for hardening actions of specific elements. Guikema et al. [12] used a Monte Carlo (MC) method to estimate the failure rates of different components and study the effects of hurricanes. Nateghi et al. [13] used statistical methods to estimate the duration of electric power outages, including variables that measure the intensity of the event, the geographical and population characteristics of the affected area and the reason for the disruption. In a recent study, Eskandarpour and Khodaei [14] applied a machine learning model to a set of synthetic data to determine probability of outages for individual components of the electric power grid system. Others such as Ganger et al. [15] provided a 
method to control possible disturbances in the system based on frequency deviations using the Area Control Error (ACE).

\subsection{Socio-Economic Vulnerability}

Less attention has been paid, however, to the linkages between hurricanes, electric power systems and socioeconomic vulnerabilities. Mitsova et al. [16] examined the relationship between the duration of electric power outage and socioeconomic vulnerability highlighting the need for increased collaboration and information sharing between utility providers, social service providers, emergency management professionals, energy experts and residents. Using Hurricane Irma's impact on Florida as a case study, the authors found that there is positive spatial dependence between electric power outages and three socioeconomic variables: minority groups, populations with sensory, physical and mental disabilities and economic vulnerability expressed as the unemployment rate [16].

High levels of damage can expose and exacerbate the physical and socioeconomic vulnerabilities of communities and households $[17,18]$. Socioeconomic vulnerability is produced by unequal exposure to risk coupled with unequal access to resources [19]. People's capacity to anticipate, cope with, resist and recover from the impacts of a natural hazard is influenced by a range of socioeconomic factors, including race, class, ethnicity, age, gender, educational attainment, income, poverty, housing tenancy, disability and immigration status $[1-3,19,20]$.

Researchers have found that low income neighborhoods recover at a slower pace $[17,18,21,22]$. Dash et al. ([22], p. 14]) found that recovery was slow and uneven, especially for minorities, one year after Hurricane Andrew hit and destroyed underserved communities such as South Miami Heights in Florida. The scholars also noted factors such as slow and/or inadequate insurance payouts, loss of family income and contractor fraud lead to slower recovery [22]. Peacock et al. [17] and Van Zandt and Sloan [18] reported that lower-value homes in Galveston, Texas, took longer to rebuild, compared to higher-value homes which typically recovered after two years.

\subsection{Insurance Coverage}

While socio-economic vulnerability may make it harder for communities to rebuild, having hazard insurance coverage can facilitate and improve household recovery processes ([3], p. 818]). In addition to wind insurance and other forms of hazard insurance purchased from the private sector, the government provides flood insurance via the federally-funded and managed National Flood Insurance Program (NFIP). However, despite the availability of this mechanism, only 12 percent of American homeowners had a flood insurance policy according to a 2016 poll by the Insurance Information Institute [23]. While coastal counties and those prone to flooding tend to have higher rates of flood insurance coverage, overall levels are still extremely low. An analysis in 2017 showed that only 17 percent of homeowners in the eight counties most directly affected by hurricane Harvey had flood insurance policies [24]. Florida in particular has the highest number of NFIP policies [25].

A detailed analysis of the demand for NFIP policies in Florida over six consecutive years (2000-2005) by Michel-Kerjan and Kousky [25] found that most NFIP policies in Florida were for single-family, residential properties ([25], p. 376). Further, in terms of market penetration by county, NFIP policies were highly concentrated in a few counties, mostly in south Florida (Monroe, Broward, Charlotte and Lee), with the exception of Franklin county in the Florida panhandle. Hurricanes in 2004 did however, lead to a 6 percent increase from 2004 to 2005, as compared to 1-2 percentage point increases between 2000 and 2005 [25]. In a similar study of flood insurance policies for Atlantic and Gulf coast states between 2001 and 2010, Kousky [26] found that Louisiana and Florida had the highest mean take-up rate across the time period and that being hit by at least one hurricane in the previous year increased net flood insurance purchases by $7.2 \%$. However, the positive effects on insurance purchases due to hurricane experiences was short-lived. Kousky [26] reports that this effect fades away within three years. Other studies have found similar effects. For example, an in-depth analysis 
of the National Flood Insurance Program showed that of the 841,000 new policies bought in 2001, only 73 percent were still in force one year later and only 20 percent were still in force eight years later [27]. Insurance costs are often a key factor affecting households' decisions to purchase wind and flood insurance.

Shan et al. 2017 [4] study the individual household's decision to purchase insurance and retrofits using an expected utility framework. They find that households' decisions to purchase insurance and to adopt retrofit actions to homes (a form of self-insurance) or to do anything at all are affected by loss distributions but these can have geographically differentiated effects. In addition, they find that the costs to purchase insurance are among the primary drivers of decisions with regard to insurance purchases and retrofitting and that subsidies for retrofit costs could be effective in mitigating the under-adoption rates and the reduction in uninsured losses due to retrofitting could offset the costs of the subsidy. Given prior research, our expectation is that while the percentage of households with insurance may not be high, having insurance would positively affect households' recovery perceptions.

\subsection{Disaster Assistance}

Federal disaster assistance can provide crucial assistance to households and can facilitate the recovery process. However, there are several factors affecting levels of government aid. While a Presidential Disaster Declaration (PDD) for a disaster-affected area allows for the disbursement of federal disaster assistance, past studies on the topic have shown that the issuing of a PDD itself is contentious and subject to political influence [28-31]. Even after a PDD has been issued, disaster assistance is limited in scope, can take time for processing and approval rates are often lower than expected. In terms of scope, the primary form of assistance provided by the Federal Emergency Management Agency (FEMA) once a disaster has been declared is through the Individual and Household Program (IHP) that provides financial help or direct services. These include housing assistance (including Temporary Housing, Repair, Replacement and Semi-Permanent or Permanent Housing Construction) and other needs assistance (for personal property and other items lost) [32].

The financial assistance provided via Individual and Household Assistance grants are usually small and not all applications are approved. For instance, in a detailed study on disaster aid following disaster events (flooding, storms and tornadoes) in 2008 in Missouri, Kousky [33] found that the average Individual Assistance (IA) grant was a little over $\$ 2000$ and that across all the 2008 disaster declarations in Missouri, the denial rate was always over 50\% ([33], p. 333). Similarly, after the 2015 floods that caused damage to a number of homes and for which a PDD was issued for 35 counties in South Carolina, only $28 \%$ of nearly 100,000 household applications for federal assistance for housing and home repair were approved ([34], p. 14). While many reasons may underlie the low percentage of approval of household applications, some of them include the difficulties of applying for assistance [35] and navigating bureaucratic processes [36]; misunderstandings about eligibility criteria [33]; and difficulties experienced by poorer households, minorities and by those speaking different languages in going through protracted qualification processes to obtain federal financial assistance [37]. Van Zandt and Sloan [18] also documented how "deferred maintenance" clauses (applied to homes that are already in poor repair) were used to deny over 6000 claims in the aftermath of Hurricanes Dolly and Ike in 2008.

\section{Methods and Measurements}

\subsection{Study Area}

The survey instrument used was administered in 30 counties in central and south Florida. Historical records of hurricane activity stretching over 152 years (1851-2003) indicate that six of the counties included in the study area (Monroe, Miami Dade, Martin, Collier, Broward and Palm Beach) are among the top ten counties with the highest probabilities of a hurricane strike along the Atlantic seaboard and the Gulf of Mexico [38]. The area was affected by Hurricane Matthew in 2016 
(28 September-10 October 2016) and Hurricane Irma (30 August-12 September 2017). Hurricane Irma made landfall near Marco Island in Collier county with an estimated landfall intensity of $100 \mathrm{kt}$ $(185 \mathrm{~km} / \mathrm{h})$ [39]. The hurricane caused property damage and disruptions to the electric power system throughout the study area. As Figure 1 indicates, most of the surveyed counties were partially or entirely within the hurricane-force wind swath.

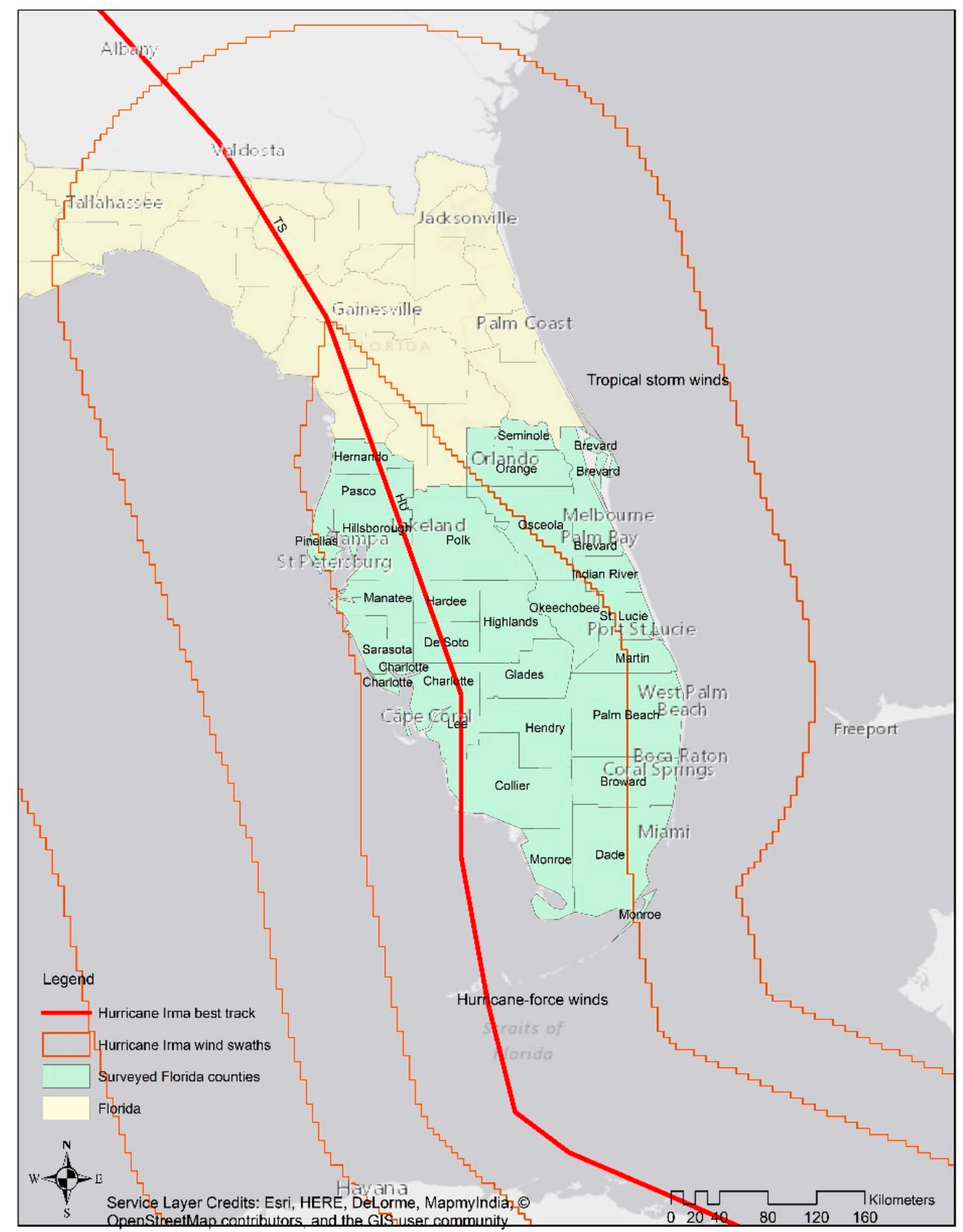

Figure 1. Surveyed Florida's counties in the path of Hurricane Irma (30 August-13 September 2017). The red line indicates Irma's best track. The isolines show the areas of hurricane-force and tropical storm winds.

The counties in the study area are home of over 15.2 million people and include major cities such as Miami, Tampa and Orlando. The area is ethnically and racially diverse with $12.3 \%$ Black/African American population and 22.7\% Hispanic/Latino population [40]. According to the U.S. Census Bureau, approximately $16.6 \%$ of the population of the study area lived under the federal poverty level 
in 2010 [40]. Nearly 3.26 million or $21.5 \%$ of the residents of central and south Florida are above the age of 65 [40]. High poverty rates that often disproportionately impact the elderly and youth further compound the vulnerability of the area to natural disasters and the process of post-disaster household and community recovery.

\subsection{Data Collection}

We designed a survey consisting of thirty questions divided into 5 sections: evacuation decisions, infrastructure disruptions, access to vital community services, insurance coverage, disaster assistance and demographic and socio-economic characteristics. The survey, composed of closed questions, was administered in May 2018. The data were collected using a mixed mode of participant recruitment via a landline telephone platform and an online platform. The data collection process was designed to capture a broader spectrum of respondents and reduce survey costs. We used random probabilistic sampling (landline telephone survey) and non-probability sampling (online survey) methods to obtain respondents. The combined sample included 989 respondents over the age of 18 . A screening question was set at the beginning of the survey to exclude those who are younger than 18 years old. In addition, the survey was conducted in English and Spanish languages. Responses in the combined sample were weighted by gender, age, educational attainment and ethnicity/race to reflect the distribution of the population in the study area.

The telephone survey was administered using an Automated Telephone Interviewing (ATI) technology which integrates automatic phone systems and software that call individuals and conduct telephone surveys. Telephone numbers were drawn randomly from a sample of 100,000 Florida residents. The phone lists for ATI were supplied by Aristotle, Inc. (http://aristotle.com/ voterlists/). Automated Telephone Interviewing allows individuals to answer questions without human intervention. That is, callers respond to questions by either pressing phone keys or by responding with voice answers that are recorded for later analysis. Automated surveys have been found to be very accurate and eliminate any possibility of bias on the part of the survey taker. All surveyed individuals receive the same question presented by using a recorded message. This eliminates dialect or questioner bias and allows the respondent to answer questions more frankly, rather than being concerned about correctness. The ATI sample consisted of $n=334$ with a response rate of $8.9 \%$.

The online sample was administered through Survey Sampling International (https:/ /www. surveysampling.com/) which is a worldwide leader in survey sampling and data collection for 38 years. SSI improves the quality and representative nature of its online sample by incorporating a wide and diverse audience and by distributing surveys across a variety of digital sources such as online communities, social networks, emails, in-app alerts and websites. Finally, to avoid self-selection bias, specific project details were not included in the invitation to participate in survey. The online sample consist of $n=655$ with a response rate of $27.5 \%$.

\subsection{Statistical Modeling}

A logistic regression model quantifies the strength of the association between a set of explanatory variables and the dependent variable. A logistic regression model with multiple explanatory variables can be represented as (Equation (1)):

$$
\operatorname{logit}[P(Y=1)]=\alpha+\beta_{1} x_{1}+\beta_{2} x_{2}+\beta_{3} x_{3}+\ldots+\beta_{k} x_{k}
$$

where $P(Y=1)$ is the probability that the expected outcome equals 1 given a set of $k$ predictors and values of $x=\left(x_{1}, x_{2}, \ldots, x_{k}\right)$ ([41], p. 182). The parameter $\beta_{k}$ reflects the effect of $x_{k}$ on the log odds that $Y=1$, adjusting for the effects of the other variables included in the model. A description of the dependent and the independent variables follows. All statistical modeling was conducted using Stata version 14 (StataCorp LP, College Station, TX, USA). Frequency tables and descriptive statistics were generated using SPSS v25 [42]. 


\subsection{Dependent Variable}

We asked respondents in 30 Florida counties to rate their overall recovery from Hurricane Irma eight months after the landfall. We asked the respondents whether they (1) completely recovered; (2) mostly recovered; (3) somewhat recovered; (4) not recovered at all; or (5) were not affected by Hurricane Irma. The responses of those who indicated that they were not affected by Hurricane Irma $(2.2 \%)$ were removed from further analysis. Overall, $69.2 \%$ of the respondents indicated that they completely recovered, $22.3 \%$ said that they mostly recovered, $9.3 \%$ said that they somewhat recovered and $5.5 \%$ reported that they did not recover at all. Categories 1 (completely recovered) and 2 (mostly recovered) were grouped in a new category named "recovered." Categories 3 (somewhat recovered) and 4 (not recovered at all) were grouped to generate a new category named "not recovered." In the logistic regression modeling, the newly created dichotomous variable (where "recovered" was coded as 1 and "not recovered" as 0 ) was used as the dependent variable. We collapsed the data into a binary dependent variable to better understand the effects of the predictors on the overall recovery process.

\subsection{Independent Variables}

Hurricane Irma track and wind swath data were downloaded from the National Hurricane Center GIS Archive. The wind swath data were intersected with the zip code tabulation areas to identify the areas affected by hurricane-force winds (coded as 1) and areas that experienced tropical storm winds (coded as 0 ). Respondents were asked whether Hurricane Irma caused damage to their place of residence considering four levels of potential damage: (1) no damage; (2) minor damage; (3) some damage; and (4) severe damage. The relationship between recovery and the impact of infrastructure disruptions was also examined. Three variables were sequentially added to the statistical models: (i) electric power outage duration; (ii) duration of cell phone and internet service disruptions; and (iii) an infrastructure disruption index calculated as the average duration of both electrical service and cell phone/internet service loss. In addition, the statistical association between recovery and the assistance received from the Federal Emergency Management Agency (FEMA), other government agencies and charities, as well as the effect of homeowners' or renters' insurance, were evaluated. The statistical association between recovery and demographic characteristics such as age, race/ethnicity and income was also examined. Table 1 provides a summary of the demographic characteristics of the survey population.

Table 1. Demographic profile of the survey population: central and south Florida, May 2018.

\begin{tabular}{|c|c|c|c|c|c|}
\hline Variable & Categories & Percent & Variable & Categories & Percent \\
\hline \multirow[t]{3}{*}{ Gender } & & & Housing tenure & & \\
\hline & Male & 48.3 & & Own & 69.3 \\
\hline & Female & 51.7 & & Rent & 30.7 \\
\hline \multirow[t]{5}{*}{ Age } & & & Education & & \\
\hline & $18-24$ & 10.1 & & \multirow{4}{*}{$\begin{array}{l}\text { Less than high school } \\
\text { High school graduate } \\
\text { Some college/trade } \\
\text { school } \\
\text { College/postgraduate } \\
\text { degree }\end{array}$} & 13.4 \\
\hline & $25-39$ & 24.2 & & & 27.7 \\
\hline & $40-64$ & 42.0 & & & 20.0 \\
\hline & 65 or older & 23.7 & & & 39.0 \\
\hline \multirow[t]{6}{*}{ Race/Ethnicity } & & & Income & & \\
\hline & White/Caucasian & 49.0 & & $\$ 0-\$ 25,999$ & 26.3 \\
\hline & Hispanic/Latino & 30.8 & & $\$ 26,000-\$ 49,999$ & 25.3 \\
\hline & Black/African American & 15.4 & & $\$ 50,000$ to $\$ 99,999$ & 26.2 \\
\hline & Other ${ }^{*}$ & 4.6 & & $\$ 100,000$ to $\$ 149,999$ & 11.5 \\
\hline & & & & More than $\$ 150,000$ & 8.9 \\
\hline
\end{tabular}

* Other includes American Indian/Alaska Native (0.2\%), Asian or Pacific Islander (2.5\%) and two or more races $(1.9 \%)$. 


\section{Results}

The initial dataset contained 989 respondents; however, the responses of those who indicated that they were not affected by Hurricane Irma were excluded from further analysis, leaving 936 respondents for inclusion in the final dataset. Figure 1 displays the study area indicating the zip codes impacted by hurricane-force winds and the zip codes remaining within the tropical wind swath.

\subsection{Characteristics of the Survey Participants}

The survey respondents were $48.3 \%$ male and $51.7 \%$ female. With regard to race and ethnicity, the respondents were $49 \%$ White, 30.8\% Hispanic/Latino, 15.4\% Black/African American and 5.6\% other including Asian or Pacific Islander (2.5\%), American Indian/Alaska Native (0.2\%) or two or more races (1.9\%). Approximately $42 \%$ of the respondents were in the age group of 40 to $64,24.2 \%$ were in the age group of 25 to $39,23.7 \%$ in the age group of 65 or older and $10.1 \%$ in the age group of 18 to 24 . With regard to the highest degree or level of schooling completed, $13.4 \%$ indicated that they had less than high school, $27.7 \%$ were high school graduate, $20 \%$ had some college or have completed a vocational school and $39 \%$ has a college or postgraduate degree. Approximately $26.3 \%$ of the respondents indicated that they made between $\$ 0$ and $\$ 25,999$ during the past 12 months, $25.3 \%$ made between $\$ 26,000$ and $\$ 49,999$ and $26.2 \%$ made between $\$ 50,000$ and $\$ 100,000$ which indicates a relatively even income distribution for the majority of the respondents with a decreasing response rate from the groups in higher income groups (11.5\% for the income group $\$ 100,000$ to $\$ 150,000$ and $8.9 \%$ for those with income above $\$ 150,000)$. Overall, $69.3 \%$ of the survey respondents were homeowners while $30.7 \%$ were renters. Among those who owned their homes, $58.6 \%$ had insurance compared to $10.7 \%$ who did not have insurance. Only $10.8 \%$ of the respondents who rented their place of residence had insurance while $19.9 \%$ did not have insurance.

\subsection{Infrastructure Disruptions Following Hurricane Irma}

In the aftermath of Hurricane Irma, $49.5 \%$ of the respondents indicated that they lost electric power for more than two days. Among those respondents, $17.3 \%$ reported that they lost electric power for two to three days, $19.5 \%$ between four and seven days and $12.5 \%$ for more than seven days. Similarly, $35 \%$ of the respondents lost a cell phone and internet service for more than two days. Nearly $14.2 \%$ remained without cell phone service or internet for two to three days, $11.6 \%$ between four and six days and $9.3 \%$ for more than seven days. Approximately $59.2 \%$ of the survey participants reported that in the aftermath of Hurricane Irma they were most concerned about extended electric power outages and lack of backup power (i.e., generators). Additionally, $9.3 \%$ were concerned about road conditions and $6.9 \%$ expressed concerns about the potential loss of cell phone or internet services. Nearly $9.8 \%$ of the survey participants reported that they were concerned about the shortage of basic supplies such as food, water and fuel while $3.6 \%$ shared concerns related to the lack of running water and sanitation. Among the survey respondents, $2.3 \%$ reported concerns related to health issues and getting access to medications.

\subsection{Insurance and Disaster Assistance}

Overall, $37.7 \%$ of the respondents indicated a lack of flood or wind insurance. Twenty-four percent reported that they had only flood insurance while $16.6 \%$ said that they had only wind insurance. Among the respondents, only $21.6 \%$ indicated that they had both wind and flood insurance. When asked whether they received disaster assistance from FEMA, other government agencies or charities, $22.8 \%$ of the respondents reported that they have received federal disaster assistance while $44.5 \%$ indicated that their application was denied. Approximately $12 \%$ said that their application was still pending. 


\subsection{Logistic Regression Analysis}

The survey results show that Hurricane Irma has disrupted many core elements of participants' lives impacting the process of recovery. Using a set of logistic regressions, we examined whether there is a statistically significant association between recovery and several variables, including: participants' characteristics; physical exposure (wind swath); severity of damage; days without basic infrastructure services; insurance coverage; and disaster assistance. Model 1 examines the effect of electric power outage duration on recovery while Model 2 evaluates the association between loss of cell phone/internet services and recovery (Table 2). In Model 3, the infrastructure disruption index (the average of the days without electricity and cell phone/internet services) was added as a covariate to the logistic regression (Table 3).

In all three models, there is no evidence of a statistically significant association between physical exposure to hurricane-force winds and recovery. However, the severity of damage was found to be a highly statistically significant predictor of recovery. The odds ratios indicated that those respondents who suffered some damage were 3.4 times less likely to recover within the months following Hurricane Irma $(p<0.001)$ while those who suffered severe damage were 19.2 times less likely to recover $(p<0.001)$.

All three models indicate that there is evidence of a statistically significant association between the recovery process and the number of days without electric power and cell phone and internet communications. Duration of electric power outages and lack of cell phone and internet communications of 2 to 7 days is statistically significant at the 0.05 confidence level while electric power outages of more than seven days is highly statistically significant $(p<0.001)$. The infrastructure disruption index in Model 3 is also found to be highly statistically significant $(p<0.001)$ indicating that the duration of infrastructure disruptions affects the process of household recovery in the months following the landfall. All three models suggests that there is evidence of a statistically significant association between recovery and insurance coverage (for both homeowner's and renter's insurance) $(p<0.10)$.

In Models 1, 2 and 3 denial of assistance has a negative effect on recovery compared to the reference group (those who received assistance). The estimates (column 5) show these effects are -2.45 , -1.78 and -2.18 , respectively. The odds ratio (column 3 ) represents the odds that an outcome will occur given a particular intervention, compared to the odds of the outcome occurring in the absence of that intervention. The odds ratios for denial of assistance are $0.245,0.368$ and 0.293 , respectively. This means that the odds of those who did not receive assistance are reduced by approximately $74.5 \%, 63.2 \%$ and $70.7 \%$ compared to those who received assistance, respectively. The results (Model 3) indicate that those respondents whose disaster assistance applications were denied are $3.4(1 / 0.293)$ less likely to report that they have completely recovered compared to those who received disaster assistance.

The results also indicate that there is a statistically significant association between recovery and demographic characteristics of households: age, race/ethnicity and income. The results for age indicate that age has a negative effect on the perception of recovery. One potential explanation could be that older respondents are more likely to be homeowners. Table 1 shows the proportion of homeowners and renters across various age groups. For age groups $18-24$ and $25-39$ in our sample, the proportion of homeowners is roughly equivalent to the proportion of renters. Among the respondents of the survey, the proportion of homeowners increases significantly for age groups 40-64 and 65 and older. However, the directional measures of association for nominal variables Lambda, the Goodman and Kruskal tau and uncertainty coefficient do not suggest strong association between age and homeownership. Overall, people who are 65 and older, as well as Black/African American and Hispanic/Latino populations, are less likely to completely recover within a few months after a hurricane landfall compared to younger or Caucasian constituencies. 
Table 2. Odds ratios and parameter estimates for logit model of recovery by covariates related to damage, duration of outages and service disruptions, insurance coverage, disaster assistance, age, race/ethnicity, income and wind swath $(1=$ recovered, $0=$ not recovered $)$.

\begin{tabular}{|c|c|c|c|c|c|c|c|c|c|c|}
\hline \multirow[t]{2}{*}{ Covariates } & \multicolumn{2}{|r|}{ Categories } & Odds Ratio & Std. Error & Estimate & Sig. & Odds Ratio & Std. Error & Estimate & Sig. \\
\hline & & & \multicolumn{4}{|c|}{ Model 1} & \multicolumn{4}{|c|}{ Model 2} \\
\hline \multirow[t]{4}{*}{ Damage } & 1 & Not at all & & & & & & & & \\
\hline & 2 & Minor & 0.764 & 0.274 & -0.75 & & 0.695 & 0.250 & -1.01 & \\
\hline & 3 & Some & 0.292 & 0.103 & -3.49 & $* * *$ & 0.229 & 0.080 & -4.20 & $* * *$ \\
\hline & 4 & Severe & 0.052 & 0.021 & -7.49 & $* * *$ & 0.047 & 0.018 & -7.84 & $* * *$ \\
\hline \multirow[t]{6}{*}{ How long $\mathrm{w} / \mathrm{o}$ power? } & 1 & No loss of power & & & & & & & & \\
\hline & 2 & A few hours & 0.784 & 0.457 & -0.42 & & & & & \\
\hline & 3 & 1 day or less & 0.358 & 0.174 & -2.11 & $* *$ & & & & \\
\hline & 4 & $2-3$ days & 0.354 & 0.163 & -2.26 & $* *$ & & & & \\
\hline & 5 & 4-7 days & 0.271 & 0.120 & -2.95 & $* *$ & & & & \\
\hline & 6 & More than 7 days & 0.188 & 0.086 & -3.65 & $* * *$ & & & & \\
\hline \multirow[t]{6}{*}{ How long $\mathrm{w} / \mathrm{o}$ cell/internet? } & 1 & No loss of service & & & & & & & & \\
\hline & 2 & A few hours & & & & & 0.413 & 0.166 & -2.20 & $* * *$ \\
\hline & 3 & 1 day or less & & & & & 1.118 & 0.510 & 0.25 & \\
\hline & 4 & $2-3$ days & & & & & 0.457 & 0.172 & -2.08 & ** \\
\hline & 5 & 4-7 days & & & & & 0.313 & 0.115 & -3.15 & $* *$ \\
\hline & 6 & More than 7 days & & & & & 0.232 & 0.090 & -3.76 & $* * *$ \\
\hline \multirow{2}{*}{ Homeowners' / renters' insurance } & 1 & Yes & 1.555 & 0.400 & 1.72 & * & 1.624 & 0.421 & 1.87 & * \\
\hline & 0 & No & & & & & & & & \\
\hline \multirow{3}{*}{ FEMA disaster assistance } & 1 & Yes & & & & & & & & \\
\hline & 2 & No, application denied & 0.245 & 0.141 & -2.45 & $* *$ & 0.368 & 0.206 & -1.78 & * \\
\hline & 3 & Application pending & 1.922 & 0.662 & 1.90 & $*$ & 1.982 & 0.693 & 1.96 & ** \\
\hline \multirow[t]{4}{*}{ Age } & 1 & $18-24$ & & & & & & & & \\
\hline & 2 & $25-39$ & 0.490 & 0.291 & -1.20 & & 0.444 & 0.265 & -1.36 & \\
\hline & 3 & $40-64$ & 0.315 & 0.183 & -1.99 & $* *$ & 0.268 & 0.156 & -2.26 & ** \\
\hline & 4 & 65 or older & 0.287 & 0.171 & -2.10 & $* *$ & 0.243 & 0.146 & -2.35 & ** \\
\hline \multirow[t]{4}{*}{ Race/ethnicity } & 1 & White & & & & & & & & \\
\hline & 2 & Black/African American & 0.566 & 0.177 & -1.83 & * & 0.600 & 0.191 & -1.61 & * \\
\hline & 3 & Hispanic/Latino & 0.422 & 0.117 & -3.12 & $* *$ & 0.499 & 0.137 & -2.52 & $* *$ \\
\hline & 4 & Other & 1.187 & 0.747 & 0.27 & & 1.125 & 0.696 & 0.19 & \\
\hline \multirow[t]{5}{*}{ Income } & 1 & $\$ 0-\$ 25,999$ & & & & & & & & \\
\hline & 2 & $\$ 26,000-\$ 49,999$ & 1.816 & 0.566 & 1.91 & * & 1.865 & 0.590 & 1.97 & ** \\
\hline & 3 & $\$ 50,000-\$ 99,999$ & 1.801 & 0.581 & 1.82 & * & 1.791 & 0.589 & 1.77 & * \\
\hline & 4 & $\$ 100,000-\$ 149,999$ & 2.930 & 1.424 & 2.21 & ** & 3.200 & 1.555 & 2.39 & $* *$ \\
\hline & 5 & More than $\$ 150,000$ & 1.397 & 0.624 & 0.75 & & 1.543 & 0.682 & 0.98 & \\
\hline \multirow[t]{2}{*}{ Wind swath } & 1 & Hurricane-force winds & & & & & & & & \\
\hline & 0 & Tropical storm winds & 1.048 & 0.249 & 0.20 & & 1.089 & 0.261 & 0.36 & \\
\hline
\end{tabular}

Notes: ${ }^{* * *} p<0.001 ;{ }^{* *} p<0.05 ; * p<0.10$ 
Table 3. Odds ratios and parameter estimates for logit model of recovery (Model 3) by covariates.

\begin{tabular}{|c|c|c|c|c|c|c|}
\hline Covariates & & Categories & Odds Ratio & Std. Error & Estimate & Sig. \\
\hline \multirow[t]{4}{*}{ Damage } & 1 & Not at all & & & & \\
\hline & 2 & Minor & 0.777 & 0.278 & -0.70 & \\
\hline & 3 & Some & 0.277 & 0.968 & -3.67 & $* * *$ \\
\hline & 4 & Severe & 0.053 & 0.021 & -7.51 & $* * *$ \\
\hline Infrastructure disruption index & & & 0.710 & 0.055 & -4.45 & $* * *$ \\
\hline \multirow[t]{2}{*}{ Homeowners' / renters' insurance } & 1 & Yes & 1.599 & 0.411 & 1.82 & * \\
\hline & 2 & No & & & & \\
\hline \multirow[t]{3}{*}{ FEMA disaster assistance } & 1 & Yes & & & & \\
\hline & 2 & No, application denied & 0.293 & 0.165 & -2.18 & $* *$ \\
\hline & 3 & Application pending & 1.919 & 0.664 & 1.88 & * \\
\hline \multirow[t]{4}{*}{ Age } & 1 & $18-24$ & & & & \\
\hline & 2 & $25-39$ & 0.467 & 0.277 & -1.28 & \\
\hline & 3 & $40-64$ & 0.288 & 0.166 & -2.16 & $* *$ \\
\hline & 4 & 65 or older & 0.267 & 0.159 & -2.22 & $* *$ \\
\hline \multirow[t]{4}{*}{ Race/ethnicity } & 1 & White & & & & \\
\hline & 2 & Black/African American & 0.551 & 0.172 & -1.91 & $*$ \\
\hline & 3 & Hispanic/Latino & 0.452 & 0.124 & -2.89 & $* *$ \\
\hline & 4 & Other & 1.088 & 0.666 & 0.14 & \\
\hline \multirow[t]{5}{*}{ Income } & 1 & $\$ 0-\$ 25,999$ & & & & \\
\hline & 2 & $\$ 26,000-\$ 49,999$ & 1.740 & 0.544 & 1.77 & $*$ \\
\hline & 3 & $\$ 50,000-\$ 99,999$ & 1.684 & 0.544 & 1.61 & * \\
\hline & 4 & $\$ 100,000-\$ 149,999$ & 2.795 & 1.357 & 2.12 & $* *$ \\
\hline & 5 & More than $\$ 150,000$ & 1.428 & 0.633 & 0.80 & \\
\hline \multirow[t]{2}{*}{ Wind swath } & 1 & Hurricane-force winds & & & & \\
\hline & 0 & Tropical storm winds & 1.026 & 0.243 & 0.11 & \\
\hline
\end{tabular}

Notes: ${ }^{* * *} p<0.001 ; * * p<0.05 ; * p<0.1$ 


\section{Discussion}

At the household level, improved insurance coverage can help homeowners rebuild and recover at a faster pace. Our results indicate that $24.1 \%$ of the surveyed households had flood insurance, $16.6 \%$ had only wind insurance and $21.6 \%$ had both. These findings are consistent with the results from an analysis conducted in the aftermath of Hurricane Harvey which showed that only $17 \%$ of homeowners in the area most affected by the record-breaking floods had flood insurance coverage [24]. Kousky ([26], p. 527-528) notes that "this protection is particularly valuable for low and moderate income families that would not be able to set aside a large enough reserve to cover damages out-of-pocket. In addition, when more homeowners and businesses are insured, it creates positive externalities in a community by speeding rebuilding and recovery and lessening the financial shock of the disaster, thus blunting negative multiplier effects." Though insurance can be a critical risk management strategy, Kousky [43] acknowledges that there are long-standing issues with insurance purchases, adequate coverage and insurance retention rates, including purchase patterns based on socio-economic status. Low-income homeowners often do not insure their homes or their homes tend to be underinsured. In the early nineties, Bolin [44] reported on the correlation between earthquake insurance purchase with income, education and occupational status. With some exceptions [43], findings on the linkages between income and the purchase of insurance have persisted in studies on flood insurance [45-48] and in research related to wind insurance [49].

Our study found that $22.8 \%$ of households' applications for federal disaster assistance were approved while $44.5 \%$ were denied. This finding corroborates the results from previous research, namely the study conducted in South Carolina after the 2015 flood events [34] where only $28 \%$ of all applications for disaster assistance were approved. As discussed earlier, while several factors may have contributed to these outcomes including the bureaucratic intricacies of the application process $[33,35,36]$, it becomes evident from this and other related studies $[16,24,34]$ that there are many difficulties experienced by low-income households and minority groups who are going through the process of receiving federal financial assistance. Our results suggest that $52 \%$ of all applications for disaster assistance were in the lower income groups $(\$ 0-\$ 49,999)$ of which $32.4 \%$ were denied. Research also suggests that FEMA funds should be available to not only rebuild a structure to its pre-disaster condition but to upgrade it and make it more resilient to future disasters. Other modifications have also been proposed for the NFIP and other forms of hazard insurance to provide adequate levels of coverage and to ensure that policies do not lapse. More effective risk communication and the use of behavioral nudges and insights from psychology and economics may also be needed to convince households to purchase and renew insurance [50].

In terms of measures for recovery of the electric power infrastructure, microgrid formation has been an active area of research [51] thanks to the capacity of these microgrids to operate in both connected and isolated ('islanded') modes and therefore serve as a preventive measure before an event and as a support to improve the restoration process after a disruption. Strategies for restoration include the utilization of the existing resources and the formation of microgrids to support areas of a collapsed system. Pham et al. [52] propose to use distributed generators to maximize the amount of load that can be restored after a blackout, sectionalizing the network to select which demand to serve and using the black-start capabilities available. Stefanov et al. [53] propose a decision tool to position resources, including units with black-start capabilities and timelines, to bring the system back after a disturbance. These authors propose several models, including optimizing the utilization of the timelines available during the restoration process, considering the minimum amount of generation adjustments required and coordinating between adjacent systems to support restoration in neighboring areas.

The emergence of cell phone and internet communications over the last two decades have facilitated sharing of disaster warning information, as well as communicating in the aftermath of disasters. Thus, there is an emerging body of literature that considers the role of cell phones and internet in disaster vulnerability and mitigation. Using cross country data on natural disaster fatalities, Toya and Skidmore [54] found that cell phone access/use reduces disaster-induced fatalities. Samarajiva 
and Waidyanatha [55] evaluated mobile technologies in Sri Lanka and they concluded that disaster risk reduction could be improved using mobile application and used to leverage the explosive diffusion of the technology even among the poor in developing countries. Jagtman [56] also evaluated the challenges and opportunities of using cell phones as part of early warning systems in the Netherlands. However, not all researchers have concluded that the use of cell phones is the most cost-effective means of disseminating disaster warning information. Quarentelli [57] presented an assessment of how potential problems with cell phone and internet communications could affect disaster preparedness and management. Specifically, the study highlights concerns about cell phone and internet service outages, which can generate sizable costs to society.

\section{Conclusions}

In this paper we use cross-sectional survey data from respondents in central and south Florida to examine the effect of Hurricane Irma on post-disaster recovery. We find that physical damage to property, disruptions of infrastructure services such as loss of electric power and cell phone/internet services and other factors (i.e., homeowner's or renter's insurance coverage, receiving disaster assistance, loss of income) are significant predictors of post-disaster recovery when controlling for age and race/ethnicity.

There are some limitations of our analysis that must be acknowledged. Disaster recovery is a long process and unfortunately our survey only takes into account one point in time during the recovery process after Hurricane Irma. Further work is needed to conduct the analysis at different times after a disaster strikes in order to analyze the pattern of recovery. In addition, in our analysis we only take into account government financial assistance through FEMA. It would be interesting to explore in future research the role of private financial assistance in terms of credit and loans from banks on households' recovery.

There are some key policy implications from this study. When the financial capacity to purchase insurance or pay mitigation costs is lacking, measures such as a means-tested flood insurance voucher program for low-income residents living in flood-prone areas and/or subsidies have been shown to be an enabling condition for securing coverage and for possible mitigation measures such as retrofitting $[4,32,58]$. In addition, we found that disaster assistance plays an important role in households' recovery. Further research is needed to better understand to what extent policy improvements of the application process, inspection of properties and efficient disbursement of funds could minimize long delays for assistance as has been the case after hurricane Harvey in Texas and Irma in Florida [59]. One of the main results of this paper is that infrastructure disruptions, particularly electric power outages delay household recovery. In most highly urbanized areas, steps have been undertaken to strengthen electrical transmission and distribution networks to minimize electric power outages. Rural areas, however, which are mostly served by municipally-owned utilities and rural cooperatives, require additional investments to strengthen their response capabilities in the aftermath of a disaster [16]. Utility regulators need to pay more attention to this issue and develop policy incentives for municipally-owned utilities and rural cooperatives to undertake more investments in strengthening transmission and distribution networks and in improving response capabilities. In addition to these policy implications, the study highlights the need for future research to expand our understanding of how measures intended to reduce infrastructure vulnerability to disruptions can enhance community resilience by simultaneously informing policies that could address socio-economic vulnerability.

Author Contributions: D.M.: helped develop the survey, conducted the data analysis and wrote parts of the study area, methods and results sections. M.E.: helped develop the survey, collected the data, wrote data collection section and wrote parts of the discussion and conclusion sections. A.S.: helped develop the survey and wrote parts of the introduction, literature review and discussion and conclusion sections. A.-M.E.: helped develop the survey and wrote parts of the literature review and discussion and conclusion sections. A.J.L.: helped develop the survey, wrote parts of the literature review and discussion and conclusion sections. All authors read and approved the final manuscript. 
Funding: This research was funded by the National Science Foundation (NSF) - grant number CMMI-1541089. However, any opinions, findings, conclusions or recommendations expressed here are those of the authors and do not necessarily reflect the views of the NSF. The APC was funded by the College of Business at Florida Atlantic University.

Conflicts of Interest: The authors declare no conflicts of interest.

\section{References}

1. Cutter, S.L.; Boruff, B.J.; Shirley, W.L. Social Vulnerability to Environmental Hazards. Soc. Sci. Q. 2003, 84, 242-261. [CrossRef]

2. Wisner, B. Vulnerability as Concept, Model, Metric and Tool. Available online: http:/ / naturalhazardscience. oxfordre.com/view/10.1093/acrefore/9780199389407.001.0001/acrefore-9780199389407-e-25 (accessed on 25 October 2018).

3. Lindell, M.K. Recovery and Reconstruction after Disaster. In Encyclopedia of Natural Hazards; Bobrowsky, P.T., Ed.; Springer: New York, NY, USA, 2013; pp. 812-824.

4. Shan, X.; Felder, F.A.; Coit, D.W. Game-theoretic Model for Electric Distribution Resiliency/Reliability from a Multiple Stakeholder Perspective. IISE Trans. 2017, 49, 159-177. [CrossRef]

5. Peng, J.; Shan, X.G.; Kesete, Y.; Gao, Y.; Davidson, R.; Nozick, L.K.; Kruse, J. Modeling the Integrated Roles of Insurance and Retrofit in Managing Natural Disaster Risk: A Multi-stakeholder Perspective. J. Nat. Hazards 2014, 74, 1043-1068. [CrossRef]

6. Kesete, Y.; Peng, J.; Shan, X.G.; Gao, Y.; Davidson, R.; Nozick, L.K.; Kruse, J. Modeling Insurer-homeowner Interactions in Managing Natural Disaster Risk. Risk Anal. 2014, 34, 1040-1055. [CrossRef] [PubMed]

7. O'Rourke, T. Critical infrastructure, interdependencies, and resilience. Natl. Acad. Eng. Bridge 2007, 37, $22-29$.

8. Wang, Y. Security of Electric Power Systems: Cascading Outage Analysis, Interdiction Model and Resilience to Natural Disasters. Ph.D. Thesis, The University of Texas at Austin, Austin, TX, USA, 2015.

9. NERC. Reliability Standards for the Bulk Electric Systems of North America; North American Electric Reliability Corporation: Atlanta, GA, USA, 2017.

10. Allen, E.; Stuart, R.; Wiedman, T. No light in August: Power system restoration following the 2003 North American blackout. IEEE Power Energy Mag. 2014, 12, 24-33. [CrossRef]

11. Ma, S.; Chen, B.; Wang, Z. Resilience enhancement strategy for distribution systems under extreme weather events. IEEE Trans. Smart Grid 2018, 9, 1442-1451. [CrossRef]

12. Guikema, S.D.; Davidson, R.A.; Liu, H. Statistical models of the effects of tree trimming on power system outages. IEEE Trans. Power Deliv. 2006, 21, 1549-1557. [CrossRef]

13. Nateghi, R.; Guikema, S.D.; Quiring, S.M. Comparison and validation of statistical methods for predicting power outage durations in the event of hurricanes. Risk Anal. 2011, 31, 1897-1906. [CrossRef]

14. Eskandarpour, R.; Khodaei, A. Machine learning based power grid outage prediction in response to extreme events. IEEE Trans. Power Syst. 2017, 32, 3315-3316. [CrossRef]

15. Ganger, D.; Zhang, J.; Vittal, V. Forecast-based anticipatory frequency control in power systems. IEEE Trans. Power Syst. 2018, 33, 1004-1012. [CrossRef]

16. Mitsova, D.; Esnard, A.-M.; Sapat, A.; Lai, B.S. Socioeconomic vulnerability and electric power restoration timelines in Florida: The case of Hurricane Irma. Nat. Hazards 2018, 94, 689-709. [CrossRef]

17. Peacock, W.G.; Van Zandt, S.; Zhang, Y.; Highfield, W.E. Inequities in long-term housing recovery after disasters. J. Am. Plan. Assoc. 2014, 80, 356-371. [CrossRef]

18. Van Zandt, S.; Sloan, M. The Texas Experience with 2008's Hurricanes Dolly and Ike. In Coming Home after Disaster: Multiple Dimensions of Housing Recovery; Sapat, A., Esnard, A.-M., Eds.; CRC Press: Boca Raton, FL, USA, 2017; pp. 83-98.

19. Bolin, B.; Kurtz, L.C. Race, Class, Ethnicity and Disaster Vulnerability. In Handbook of Disaster Research; Rodriguez, H., Donner, W., Trainor, J.E., Eds.; Springer International Publishing: Basel, Switzerland, 2018; pp. 181-204.

20. Wisner, B.; Blaikie, P.; Cannon, T.; Davis, I. At Risk: Natural Hazards, People's Vulnerability, and Disaster, 2nd ed.; Routledge: London, UK, 2004; pp. 3-48.

21. Dash, N.; Peacock, W.G.; Morrw, B.H. Hurricane Andrew: Ethnicity, Gender, and the Sociology of Disasters; Peacock, W.G., Morrow, B.M., Gladwin, H., Eds.; Routledge: New York, NY, USA, 1997; pp. 206-225. 
22. Dash, N.; Morrow, B.; Mainster, J.; Cunningham, L. Lasting Effects of Hurricane Andrew on a Working-Class Community. Nat. Hazards Rev. 2007, 8, 13-21. [CrossRef]

23. Insurance Information Institute. Facts + Statistics: Flood Insurance. 2018. Available online: https://www.iii. org/fact-statistic/facts-statistics-flood-insurance (accessed on 29 September 2018).

24. Long, H. Where Harvey Is Hitting Hardest, 80 Percent Lack Flood Insurance. The Washington Post, 29 August 2017. Available online: https://www.washingtonpost.com/news/wonk/wp/2017/08/29/ where-harvey-is-hitting-hardest-four-out-of-five-homeowners-lack-flood-insurance/?noredirect=on\& utm_term=.c16d47843bc9 (accessed on 1 November 2018).

25. Michel-Kerjan, E.O.; Kousky, C. Come rain or shine: Evidence on flood insurance purchases in Florida. J. Risk Insur. 2010, 77, 369-397. [CrossRef]

26. Kousky, C. Disasters as Learning Experiences or Disasters as Policy Opportunities? Examining Flood Insurance Purchases after Hurricanes. Risk Anal. 2017, 37, 517-530. [CrossRef] [PubMed]

27. Michel-Kerjan, E.; Lemoyne de Forges, S.; Kunreuther, H. Policy tenure under the U.S. national flood insurance program (NFIP). Risk Anal. 2012, 32, 644-658. [CrossRef]

28. Sylves, R.; Buzas, Z.I. Presidential Disaster Declaration Decisions, 1953-2003: What Influences Odds of Approval. State Local Gov. Rev. 2007, 39, 3-15. [CrossRef]

29. Garrett, T.; Sobel, R. The Political Economy of FEMA Disaster Payments. Econ. Inquiry 2003, 41, $496-509$. [CrossRef]

30. Salkowe, R.; Chakraborty, J. Federal disaster relief in the US: The role of political partisanship and preference in presidential disaster declarations and turndowns. J. Homeland Secur. Emerg. Manag. 2009, 6, 28.

31. Downton, M.W.; Pielke, R.A., Jr. Discretion without accountability: Politics, flood damage, and climate. Nat. Hazards Rev. 2001, 2, 157-166. [CrossRef]

32. Kousky, C.; Michel-Kerjan, E.O.; Raschky, P.A. Does federal disaster assistance crowd out flood insurance? J. Environ. Econ. Manag. 2018, 87, 150-164. [CrossRef]

33. Kousky, C. Facts about FEMA household disaster aid: Examining the 2008 floods and tornadoes in Missouri. Weather Clim. Soc. 2013, 5, 332-344. [CrossRef]

34. Cutter, S.L. The perilous nature of food supplies: Natural hazards, social vulnerability, and disaster resilience. Environ. Sci. Policy Sustain. Dev. 2017, 59, 4-15. [CrossRef]

35. Welsh, M.G.; Esnard, A.M. Closing gaps in local housing recovery planning for disadvantaged displaced households. Cityscape 2009, 195-212.

36. Sapat, A. Politics of Recovery: Policy and Governance Challenges in Post-Disaster Housing. In Coming Home after Disaster: Multiple Dimensions of Housing Recovery; Sapat, A., Esnard, A.-M., Eds.; CRC Press: Boca Raton, FL, USA, 2017; pp. 67-79.

37. Peacock, W.G.; Dash, N.; Zhang, Y.; Van Zandt, S. Post-Disaster Sheltering, Temporary Housing, and Permanent Housing Recover. In Handbook of Disaster Research, 2nd ed.; Rodriguez, H., Donner, W., Trainor, J.E., Eds.; Springer International Publishing: Basel, Switzerland, 2018; pp. 569-594.

38. Esnard, A.M.; Sapat, A.; Mitsova, D. An index of relative displacement risk to hurricanes. Nat. Hazards 2011, 59, 833-859. [CrossRef]

39. Cangialosi, J.P.; Latto, A.S.; Berg, R. Hurricane Irma. National Hurricane Center Tropical Cyclone Report. Available online: https:/ / www.nhc.noaa.gov/data/tcr/AL112017_Irma.pdf (accessed on 23 October 2018).

40. U.S. Census Bureau. Available online: http://www.census.gov (accessed on 10 October 2018).

41. Agresti, A. Categorical Data Analysis, 3rd ed.; John Wiley \& Sons: Hoboken, NJ, USA, 2013; p. 182.

42. IBM Corp. IBM SPSS Statistics for Windows; Version 25.0, released 2017; IBM Corp.: Armonk, NY, USA, 2017.

43. Kousky, C. Understanding the demand for flood insurance. Nat. Hazards Rev. 2011, 12, 96-110. [CrossRef]

44. Bolin, R.C. Household and Community Recovery after Earthquakes; University of Colorado Institute of Behavioral Science: Boulder, CO, USA, 1993.

45. Atreya, A.; Ferreira, S.; Michel-Kerjan, E. What drives households to buy flood insurance? New evidence from Georgia. Ecol. Econ. 2015, 117, 153-161. [CrossRef]

46. Browne, M.; Hoyt, R. The demand for flood insurance: Empirical evidence. J. Risk Uncertain. 2000, 20, $291-306$. [CrossRef]

47. Landry, C.; Jahan-Parvar, M. Flood insurance coverage in the coastal zone. J. Risk Insur. 2011, 78, 361-388. [CrossRef] 
48. Kriesel, W.; Landry, C. Participation in the National Flood Insurance Program: An empirical analysis for coastal properties. J. Risk Insur. 2004, 71, 405-420. [CrossRef]

49. Wang, D.; Davidson, R.; Trainor, J.; Nozick, L.; Kruse, J. Homeowner purchase of insurance for hurricane-induced wind and flood damage. Nat. Hazards 2017, 88, 221-245. [CrossRef]

50. Lindell, M.K.; Brody, S.D.; Highfield, W.E. Financing Housing Recovery through Hazard Insurance: The case of the National Flood Insurance Program. In Coming Home after Disaster: Multiple Dimensions of Housing Recovery; Sapat, A., Esnard, A.-M., Eds.; CRC Press: Boca Raton, FL, USA, 2017; pp. 49-66.

51. Eskandarpour, R.; Lotfi, H.; Khodaei, A. Optimal micro-grid placement for enhancing power system resilience in response to weather events. In Proceedings of the 2016 North American Power Symposium, Denver, CO, USA, 18-20 September 2016; pp. 1-6.

52. Pham, T.T.H.; Besanger, Y.; Hadjsaid, N. New challenges in power system restoration with large scale of dispersed generation insertion. IEEE Trans. Power Syst. 2009, 24, 398-406. [CrossRef]

53. Stefanov, A.; Liu, C.; Sforna, M.; Eremia, M.; Balaurescu, R. Decision support for restoration of interconnected power systems using tie lines. IET Gener. Transm. Distrib. 2015, 9, 1006-1018. [CrossRef]

54. Toya, H.; Skidmore, M. Cellular telephones and natural disaster vulnerability. Sustainability 2018, 10, 2970. [CrossRef]

55. Samarajiva, R.; Waidyanathan, N. Two complementary mobile technologies for disaster warning. Info 2009, 11, 58-65. [CrossRef]

56. Jatman, H.M. Design for safety: A new service for alarming and informing the population in case of emergency. Infranomics Sustain. Eng. Des. Gov. 2014, 24, 103-124.

57. Quarantelli, E.L. Problematical aspects of the information/communication revolution for disaster planning and research: Ten non-technical issues and questions. Disaster Prev. Manag. 1997, 6, 94-106. [CrossRef]

58. Michel-Kerjan, E.; Kunreuther, H. Redesigning flood insurance. Science 2011, 333, 408-409. [CrossRef]

59. Fernandez, M.; Alvarez, L.; Nixon, R. Still Waiting for FEMA in Texas and Florida After Hurricanes. New York Times, 22 October 2017. Available online: https:/ /www.nytimes.com/2017/10/22/us/fema-texasflorida-delays-.html (accessed on 13 October 2018).

(C) 2019 by the authors. Licensee MDPI, Basel, Switzerland. This article is an open access article distributed under the terms and conditions of the Creative Commons Attribution (CC BY) license (http:/ / creativecommons.org/licenses/by/4.0/). 